\title{
Re/nationalising EU-rope
}

\author{
National Identities, Right-Wing Populism, and Border-and Body-Politics
}

\author{
Ruth Wodak
}

\begin{abstract}
In almost every EU member state, and beyond, we are experiencing the rise of farright/right-wing populist parties, accompanied by a virulent (nativist) nationalism and related body and border politics. Not only are borders being closed and walls constructed, in order to keep specific groups of people (refugees and immigrants) out; the programs also contain many elements of a patriarchal, anachronistic gender and family politics. This contribution discusses such nationalistic body politics which has become visible in many election campaigns and in, for example, the notorious 'headscarf debate', the 'Burkini debate', and the debate about the so-called 'unwillingness to integrate'. The contribution then proceeds to a qualitative case study on how the Austrian Freedom Party has recontextualised the discourse about 'Volk' and 'Volkskörper' in recent years, in order to advance its populist, xenophobic and gendered agenda and to normalise their far-right political positions. Using the Discourse-Historical Approach (DHA), it discusses the complex strategies with which the party has combined backstage and frontstage approaches in this struggle for a new discursive hegemony.
\end{abstract}

\section{Introduction}

Since the 1980s, the transformation of the former Eastern bloc, Germany's reunification, the enlargement and deeper integration of the European Union, together with persistent debates on immigration, migration and flight, focused attention on issues of historical and cultural (local, regional and national) identities. In the Member States of the European Union, the propagation of a new European identity was accompanied by the emergence or re-emergence of fragmented and unstable national and ethnic identities. Seemingly established collective, national identities became contested political terrain and the focus of political struggles. Research focusing on the constitutive role of 
discourse - and particularly language - in the construction of national identities ${ }^{1}$ has drawn on the valuable contributions in historiography, sociology and political science. $^{2}$

More recently, threats and crises of various kinds have re-invigorated discussions of national or cultural identities across Europe. Thus, nationalism, once declared an obsolete force, especially after World War II and the establishment of the European Union, has obviously returned with renewed vigour. Nationalism nowadays must be perceived as a global phenomenon - we encounter passionate nationalist movements everywhere, in Africa, South-America, the Middle East, Southern Europe, and in the successor states of the former Soviet Union. Frequently, new nationalisms emerge, tied to religious beliefs such as Islamic nationalism. Indeed, it seems to be the case that - despite an ever more unified and globalised world -, more borders and walls emerge, defining nation states and protecting them from dangers both alleged and real.

Of course, it is important to emphasize that the idea of the nation also encompasses inclusiveness and solidarity; simultaneously, belonging to a nation is frequently defined through ethnic and even racist categories (rather than, e.g., legal citizenship), thus excluding 'Others' who do not possess these characteristics and are marginalised as outsiders, as strangers. In this way, our identities are inherently tied to subjective feelings of belonging, on the one hand; as well as to imposed nationalistic, religious, and ethnic categories, on the other. Identity, in this complex struggle over belonging, is never static and defined once and for all; identity and identities are dynamic, fluid and fragmented; they can be renegotiated, according to socio-political and situative contexts as well as to more global social change and ideologically informed categories. Therefore, the German sociologist Theodor W. Adorno famously claimed, "[i]dentity is the prototype of ideology".

Taking Adorno's words on board, the manifold ways in which national identity and nationalism are functionalised nowadays by right-wing populist and far-right parties with the aim of, on the one hand, constructing the 'real' Hungarians, Austrians, Dutch, Finns or British and, on the other, of excluding all the 'Others' who are considered as not belonging to the respective group, should be investigated. Delanty and Kumar rightly emphasize that "nationalism is present in almost every aspect of political community and social arrangements. It pervades the global and local dimensions and can even take cosmopolitan

\footnotetext{
1 See Boukala (2013); Sicurella (2016); Krzyżanowski (2010); Wodak et al. (2009); Wodak (2011); (2015a), (2015b), (2017), (2019a).

2 See Gellner (1983); Anderson (1995); Haller et al. (1996); Rathkolb (2011); Billig (1995).

3 Adorno (1966), p. 151.
} 
forms". ${ }^{4}$ The 'real' people are defined not by having obtained citizenship to a specific country (ius soli), but by having been born to parents who already belonged to the respective country, i.e., by nativist principles or ius sanguinis. ${ }^{5}$ If push comes to shove, this can even be extended to a vaguely defined cultural or even linguistic 'belonging'. Such opinions are held not only by the far-right; they are endorsed more and more strongly by mainstream parties who - out of fear of losing votes - accommodate such right-wing populist views. Because of continuous fear mongering related to debates about security and the protection of 'our social welfare' (social welfare chauvinism), the ground has shifted. ${ }^{6}$

With respect to Austrian national identities, these developments have been the subject of discourse-analytical studies in the tradition of critical theory, leading to the elaboration of an interdisciplinary framework that integrates a form of Critical Discourse Studies with approaches from the political sciences, historiography and sociology in the Discourse-Historical Approach (DHA). ${ }^{7}$ Although the framework was developed through studies related to Austria, the theoretical as well as the general analytical findings provide insight into widespread patterns of discursive nationalisation within other modern nation-states. Indeed, the DHA has since been widely acknowledged by the international scientific community and applied in studies of the discursive construction of national identities in numerous countries in Europe and South America, but also in Canada, the USA, Australia and China. ${ }^{8}$

The year 2015 offered a unique opportunity to continue previous research into the discursive construction of Austrian identity and in so doing update the underlying approach and framework. On the one hand, 2015 was a significant commemorative year for Austria - 20 years of EU membership, 70 years since the Declaration of Independence, 6o years since the State Treaty, 200 years since the Congress of Vienna, 650 years for the University of Vienna. On the other hand, it presented the opportunity to trace the discursive construction of Austrian identities in a longitudinal perspective by connecting to previous work focused on and using similar data in 1995 and 2005. The resulting perspective spans analyses from over 20 years within the same theoretical framework, making it both unique and innovative in the international field of research. ${ }^{9}$

Firstly, this contribution reviews the underlying assumptions about the discursive construction of national identities and discusses the concepts of

4 Delanty, Kumar (2006), p. 3.

See Mudde (2007).

6 See Wodak (2015b).

7 See Wodak (2011); Wodak (2015a); Reisigl, Wodak (2009).

8 See for example Blackledge (2009); Ricento (2003).

9 See De Cillia, Wodak, Rheindorf, Lehner (2020). 
'nation' and 'national identity'. Secondly, I briefly present the Discourse-Historical Approach, including recent conceptual and methodological adaptations. I then thirdly focus on the Austrian far-right populist party FPÖ, both backstage and frontstage, and its nationalist nativist ideologies; and elaborate some interdependences of extreme-right positioning on backstage and frontstage while deconstructing the visions of an Austrian nativist national identity. ${ }^{10}$

Nations, following Anderson, are constructs represented in the minds, memories and social practices of nationalised subjects as sovereign and limited political units. ${ }^{11}$ Nations, like all other communities that are larger than face-to-face groups, constitute what Anderson calls "imagined communities". Nonetheless, they can function as very influential guiding ideas with sometimes grave and destructive consequences. Members of even the smallest nations do not know the majority of their fellow-citizens, do not meet, do not hear from one another. And yet they are convinced of belonging to a unique national community, not least because they largely read the same newspapers, watch the same TV programmes or listen to the same radio programs, etc. Nations are perceived as limited by boundaries and thereby cut off from the surrounding nations, because no nation identifies with humanity in its entirety.

We argue that such national identities - conceived as specific forms of social identities - are not in any biologist or culturalist sense essential or naturally given, but are discursively produced, reproduced, transformed and destructed by means of language and other semiotic systems. National identities are constructed, inter alia, by emphasising a common history, and thus through remembrance and memory. Maurice Halbwachs' notion of "collective memory" denotes the selective recollection of past events which are thought to be important for the members of a specific community. ${ }^{12}$ This notion allows researchers to trace a connection between often abstract discourses on national identities, myths, symbols and rituals of everyday life, ${ }^{13}$ or popular culture, increasingly in the form of "banal nationalism". ${ }^{14}$ Collective memory in Halbwachs' sense maintains historical continuity by recalling specific elements

\footnotetext{
10 Rheindorf, Wodak (2019).

11 See Anderson (1985), p. 15.

12 Halbwachs (1985).

13 See Breuss, Liebhart, Pribersky (1995), p. 553.

14 Billig (1995).
} 
from the archive of historical memory. This concept is of particular interest for an analytical approach to the discursive construction of national identities, especially regarding the question of which events are selected for a "national history" and how they are narrativised by a nation's representatives (e.g. the head of state), institutions (e.g. courts, schools), the media, and private citizens in constructing a shared history, present and future. ${ }^{15}$ The fact that such history is constructed through discursive practices has been described as the "anthropological primacy" of language:

[...] language becomes the primary factor without which no recollection and no scientific transposition of this recollection is possible. The anthropological primacy of language for the representation of past history thus gains an epistemological status, for it must be decided in language what in past history was necessitated by language and what was not. In anthropological terms, any 'history' constitutes itself through oral and written communication between generations that live together and convey their own respective experiences to one another. ${ }^{16}$

Approaches in cultural studies and sociology emphasize the role everyday life and culture play in the construction of nations and national identities. Stuart Hall describes nations not only as political constructs, but also as "systems of cultural representations" that allow an imagined community to be interpreted in meaningful ways. ${ }^{17}$ People are not only citizens by law, they also participate in creating the imaginary of 'their' nation as represented in a common national culture. Through such self-representation - which has a counterpart in representations of other nations - the symbolic community of a nation is discursively constructed.

A national culture is a discourse, a way to construct meanings which influence and organize both our actions and our perceptions of ourselves. National cultures construct identities by creating meanings of 'the nation', with which we can identify; these are contained in stories that are told about the nation, in memories which link its present to its past and in the perceptions of it that are constructed ${ }^{18}$

\footnotetext{
15 See Berger, Wodak (2018).

16 Koselleck (2002), p. 27.

17 Hall (1994), p. 200.

18 Hall (1994), p. 201.
} 
Beyond being simply part of culture, languages have often played a crucial role in the formation of modern nation states such as France, glossing over or actively repressing existing multilingualism through legislation, education and administrative practice. With respect to the construction of distinctiveness and homogeneity of national languages, language policy remains a key field of social and political action.

Pierre Bourdieu's notion of habitus provides a crucial perspective in the sense that national identities can be regarded as a sort of habitus, that is to say as a complex of common ideas, concepts or perception schemes, i.e. (a) related emotional attitudes intersubjectively shared within a specific group as well as (b) similar behavioural dispositions, which are (c) internalised through 'national' or 'nationalising' socialisation. ${ }^{19}$ The national subject, in other words, is discursively produced. In the case of the Austrian nation, the ideas and schemata in question refer to the imagined concept of the homo Austriacus (and the femina Austriaca), the 'quintessential' or 'typical Austrian'.

In as much as the modern nation state is a territorial state and seeks to define its extension within clear-cut geographic borders, the discursive construction of national identities relates to notions of home, homeland or 'Heimat'. What are constructed as 'natural' and 'agricultural' landscapes as well as the built environment thus constitute a type of national body that often supports identification, feelings of belonging and pride. Insofar as this body also always has a more or less extensive past, this dimension of national identity may relate closely to the shared past and may or may not be constructed as co-extensive with a national culture and/or language.

In terms of all of the above - national past, culture, language, body and self-representation - the discursive construction of national identities is always concomitant with the construction of difference/distinctiveness and uniqueness. ${ }^{20}$ In short, to be discursively constructed as Austrian may more or less strongly rely on contrast, even opposition to constructions of other national identities (e.g. German) with respect to, inter alia, the national narrative, culture or language.

As internalised habitus as well as discursive construction, the reproduction and transformation of national identities is always also a question of power relations and hegemony. The constructivist perspective outlined above emphasizes that there is no such thing as the one and only national identity in an essentialising sense, but rather that different identities are discursively constructed,

19 See Bourdieu (1994).

$20 \quad$ See Hall (1994); Hall (1996); Wodak (2017). 
co-constructed and negotiated, according to specific socio-political and situational contexts, that is according to the social field, the situational setting of the discursive act and the topic being discussed. In other words, national identities are not completely consistent, stable and immutable. Rather, as already mentioned above, they are dynamic, fragile, fluid, and often incoherent. However, previous work has shown that the relations (of transfer and contradiction) between identity constructions offered by political elites, the media and everyday discourses are not arbitrary or random but rather purposeful and contextually determined.

Border and body-politics are part of national identity politics and are now once again increasingly defined by the national language (the mother tongue), by ethnicity and culture, transcending the political borders of the nation state. ${ }^{21}$ Instead of cosmopolitanism, post-nationalism, a European citizenship and the common European language policies which promote multilingualism, we seem to be witnessing a re/inventing of traditional, parochial, closed nation states. Such tendencies have also been observed by Skendorovic who - while analysing the Swiss right-wing populist party's (SVP) policies and history - concludes that "the radical right's conception of nationhood and national identity offers patterns of interpretation premised on the idea that sociocultural, political, or historical groups are based on natural distinctions." 22 Griffin accordingly concludes that the radical right "takes on highly culture-specific forms, largely because it draws on a nationalist myth whose contents are unique to each cultural tradition". ${ }^{23}$ Obviously, the concept of 'mother tongue' relates to nativist body politics of viewing and conceptualising the nation as a body with the mother tongue symbolising the national language. ${ }^{24}$

Thus, in contrast to discursive and social constructivist approaches to nationalism elaborated above, 'nation' as defined by far-right populist parties is a limited and sovereign community that exists and persists through time and is tied to a specific territory (space), inherently and essentially constructed through an in/out (member/non-member) opposition and its out-groups. Access to national identity/membership is defined via heritage and ancestry, thus via 'blood'. ${ }^{25}$ Such a notion of nation and nationalism is closely tied to concepts underlying racism; however, it is important to emphasize here that neither is racism necessarily nationalist, nor nationalism necessarily racist. For

\footnotetext{
21 See Wodak (2015a); Rheindorf, Wodak (2018).

22 Skendorovic (2009), p. $18 \mathrm{f}$.

23 Griffin (1999), p. 316.

24 See Musolff (2010).

25 See de Cleen (2012), p. 97.
} 
example, the connection to a territorial space must be perceived as a structural component of nationalism, but not of racism. While racism as ideology and practice depends on the arbitrary definition of groups and their fallaciously generalised negative characteristics, due to biological categories, nationalism need not. Nevertheless, the conceptual boundaries are certainly blurred. ${ }^{26}$

Four assumptions serve as foundations for this analysis:

1. Identities are always re/created in specific contexts. They are co-constructed in interactive relationships. They are usually fragmented, dynamic and changeable, but not mutually exclusive - everyone has multiple identities.

2. Identity construction always implies inclusionary and exclusionary processes, i.e., definitions of 'Us' and 'Them'. Linguistic competence of the national language (the 'mother tongue') has acquired the status of a gatekeeper in posing obstacles for migrants.

3. Identities that are individual and collective, national and transnational are also re/produced and manifested symbolically, in many genres, while drawing on a range of linguistic/pragmatic/rhetorical/narrative and argumentative resources.

4. Far-right populist nationalism inherently endorses an essentialised concept of nationalism expressed in ever more restrictive (nativist) body politics (Kulturnation). Mainstream political parties accommodate more and more to essentialised national body politics to keep their electorate from voting for far-right parties and their values; in other words, far-right ideologies become normalised.

\section{The Discourse-Historical Approach}

In my case study below, I adopt the discourse-historical approach (DHA). This approach provides a vehicle for looking at latent power dynamics and the range of potentials in agents, because it integrates and triangulates knowledge about historical, intertextual sources and the background of the social and political fields within which discursive events are embedded. Moreover, the DHA distinguishes between three dimensions which constitute textual meanings and structures: the topics which are spoken/written about; the discursive strategies employed; and the linguistic means that are drawn upon to realize both topics and strategies.

26 See Reisigl, Wodak (2001); de Cleen (2012). 
The DHA is widely applied in research on identity politics, populism, discriminatory rhetoric, and so forth, and allows the systematic relating of macroand mezzo-levels of contextualisation to the micro-level analyses of texts. Such analyses consist primarily of two levels, an 'entry-level analysis' focusing on the thematic dimension of texts, and an 'in-depth analysis' which deconstructs the coherence and cohesion of texts in detail. The general aim of the entry-level thematic analysis is to map out the contents of the texts being analysed. The key analytical categories of thematic analyses are discourse topics, which, "conceptually summarize the text, and specify its most important information".27 The in-depth analysis, on the other hand, is informed by the research questions and consists of the identification of the genre (e.g., TV interview, policy paper, election poster, political speech or homepage), analysis of the macro-structure of the respective text, the strategies of identity construction and of the argumentation schemes, as well as of other means of linguistic realisation it uses.

'Discourse' is defined as follows, emphasising argumentation (i.e. people with different opinions, attitudes and ideologies speaking and arguing about the same macro-topic) and the distinction between ideology and discourse as constitutive factors from the outset:

[...] a cluster of context-dependent practices that are situated within specific fields of social action; socially constituted and socially constitutive; related to a macro-topic; linked to the argumentation about validity claims such as truth and normative validity, involving several social actors who (may) have different points of view. ${ }^{28}$

In the DHA, two further concepts emerge as salient for analysing politically salient phenomena: first, 'intertextuality' refers to the linkage of all texts to other texts, both in the past and in the present. Such links can be established through continued reference to a topic or to its main actors; through reference to the same events as other texts; or through the reappearance of a text's main arguments in another text as well as certain syntactic (grammatical) and also rhetorical schemes and other tropes. The second important process is labeled 'recontextualisation'. By taking an argument, a topic, a genre, or a discursive practice out of context and restating/realising it in a new context, we first observe the process of de-contextualisation, and then, when the respective

$27 \quad$ Van Dijk (1991), p. 113

28 Reisigl, Wodak (2009), p. 89. 
element is implemented in a new context, of recontextualisation. The element then acquires a new meaning, because meanings are formed in use.

Conceptually, the empirical event under investigation is viewed as a phenomenon that has discursive manifestations across four heuristic levels of context (see Table 5.1. below). ${ }^{29}$

TABLE 5.1 Four-level Context-Model

1. The immediate text of the communicative event in question (a particular detailed transcript of talk; a specific newspaper article; a specific speech);

2. The intertextual and interdiscursive relationship between utterances, texts, genres and discourses (e.g. conversations with the same participants in different settings);

3. The extra linguistic social (e.g. physical gestures, facial expressions, postures, etc.) and environmental (e.g. room size and layout) variables and institutional frames (e.g. latent or formal hierarchical structure, informal power relations in a friendship, cultural constraints and conventions, etc.) of a specific 'context of situation';

4. The broader socio-political and historical context which discursive practices are embedded in and related to (e.g., knowledge derived from ethnography, study of the relationships in, and aspects of, the broader social and cultural macro-environment over time that influence the text, talk and conversations).

\section{4. $\quad$ Case Study: Recontextualising the 'Volk' and the 'Volkskörper'}

The core notions of the study, as in previous work, are

1. the interdiscursively related construction of the so-called Homo Austriacus/Homo Externus,

2. the narration and construction of a shared political past,

3. a shared culture,

4. a shared political present and future, and

5. the discursive construction of a "national body".30

\footnotetext{
29 See Wodak (2011).

3o See for example Wodak et al. (2009).
} 
The integration of the first and fifth categories - the Homo Austriacus and the national body - characterise the discourse of the far- and extreme right in Austria, becoming the focal point of discursive practices and argumentative patterns, serving related constructions of 'us' versus 'them'. Such constructions emphasise national uniqueness and (inner) homogeneity and downplay heterogeneity and difference within the population. Simultaneously, they also focus on differences to members of other nations, often resorting to stereotyping and singularisation. Here, I present some extreme right elements within the far right. Indeed, the Austrian Freedom Party (FPÖ) must be distinguished from other far-right populist parties not only in some of its ideological positions, but in terms of its history and ties to National Socialism. ${ }^{31}$

The national body is constructed in terms of a nation's territory, its 'natural' landscape as well as its built environment (e.g., architecture, sites and material art), its institutions (e.g., executive, legislative, judiciary) and its national 'heroes' (in, e.g., politics, the military, sports or arts). Previous studies have linked constructions of the national body to the symbols and practices of 'banal nationalism' as identified by Michael Billig:32 Abstract and seemingly apolitical, naturalised figurations of the nation lend themselves particularly well to everyday nationalisms. At this point, the link between the national body (i.e., its salient constructions in banal nationalism) and the construction of a Homo Nationalis should be explored in more detail, in particular the gender and body politics. It is here that the traditional extreme-right imaginary of the 'Volk', imagined as ideal male and female bodies, their roles and relationships, is articulated most clearly. Below, I analyse continuities and changes of such extreme-right ideologies in the intertextual and interdiscursive relationships across genres and publics, most prominently in popular culture which recontextualises and propagates the far-right's ideal subject. To do so, I also analyse some of the backstage and frontstage performances of the contemporary far-right as well as the historical continuities with National Socialist rhetoric and imaginaries, while providing a cross-sectional analysis of the fields of politics (party politics, part-affiliated organisations and media) and popular culture (music).

$31 \quad$ Leading members of the party have been investigated for and convicted of activities such as denying the Holocaust, violating the Verbotsgesetz or Prohibition Act of 1947, which banned the Nazi Party and aimed to suppress any potential revival of Nazism. See e. g. Engel, Wodak (2013).

See Billig (1995). 


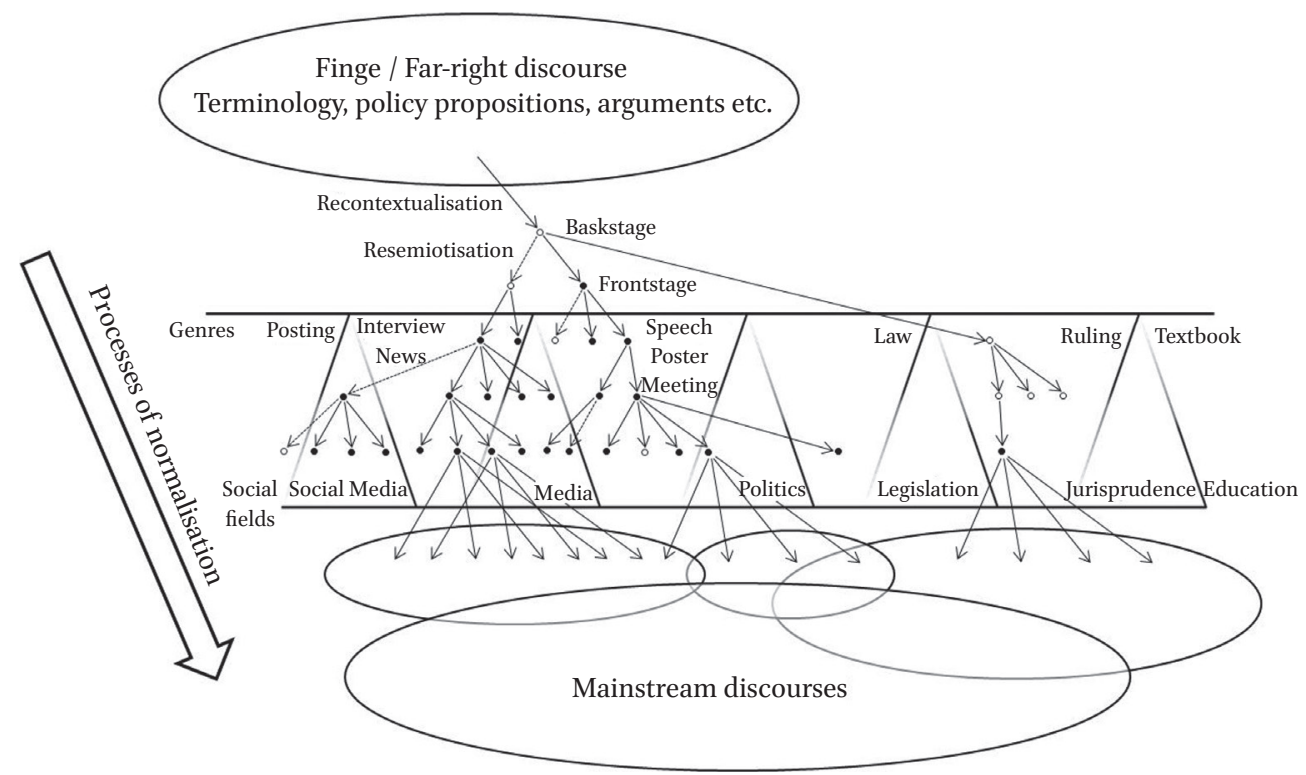

FIGURE 5.1 The normalisation of extreme-right ideology (adapted from Wodak 2019a, p.16)

Thus, one can trace continuities not only historically but across fields, showing how far-right and extreme right positions are recontextualised from closed-door meetings (i.e. backstage politics) as well as unofficial handbooks and pamphlets to election campaigns (posters, speeches, TV debates, i.e. frontstage politics) and ultimately normalised in popular culture. The advantage of such a cross-sectional approach is that it reveals the intertextual links between backstage and frontstage, i.e. the penetration of extreme-right ideology into everyday mainstream discourses as part of an ongoing process of normalisation. From the latter perspective, normalisation describes how ideologies are incorporated into the mainstream - not only of politics but of popular culture and other fields as well - through recontextualisations and resemiotisations, usually moving from backstage to frontstage, and across fields as well as genres.

\subsection{The Far-and Extreme Right in Austria: Tracing the History of the FPÖ}

The history of the FPÖ (Freiheitliche Partei Österreichs) dates back to the years after World War II and the political situation created by the four postwar Allied Powers until the 'Staatsvertrag' (State Treaty) of 1955. Between 1945 and 1955, the Allies supported the development of a bi-polar political scene by encouraging both the cooperation of socialist-democratic movements on the left and the formation of what would later evolve into the Social Democratic Party of Austria (sPÖ; Sozialdemokratische Partei Österreichs), and the merging 
of various conservative and pro-clerical movements into the Austrian People's Party (övp; Österreichische Volkspartei). Simultaneously, the forerunner of the FPÖ, the Association of Independents (VdU; Verband der Unabhängigen) was formed by incorporating political movements comprised of "old Nazis, German nationalists and a fair number of liberals", ${ }^{33}$ who were deliberately prevented from joining either of the two mainstream parties of the left and right.

In the 1949 parliamentary elections, the VdU won 12 per cent and soon called for "the abolition of all laws governing de-Nazification procedures". ${ }^{34}$ Their argument implied that the real victims were not those persecuted by the Nazi regime, but those who had profited by acquiring Jewish property and former members of the NSDAP. The VdU thus used a "grotesque conception of fascism [...] to attack the de-Nazification policies of the government and to equate Nazism with other political systems". ${ }^{35}$ Hence, the VdU allowed for a revival of Austrian pro-fascist sentiment and made it a significant element of the country's political makeup for coming years.

Following an internal crisis of the VdU, the FPÖ was established in 1955/56 "as a German nationalist party of the far right, in which former, seriously incriminated National Socialists took the leading functions". ${ }^{36}$ Indeed, the first FPÖ leader, Anton Reintaller, had been a high-ranking member of the Austrian NSDAP and the ss, but also held the position of Minister of Agriculture in the fascist Austrian government of Seyß-Inquart in 1938. All this made the FPö the successor to the Austrian NSDAP in all but its name. ${ }^{37}$

When Friedrich Peter (another former ss member) took over the FPÖ in 1958, the party's agenda did not change significantly. However, throughout the 1960s, the drive to moderate the FPÖ could be observed when both liberal and national views were given a voice. In 1970, the newly elected Chancellor Bruno Kreisky (sPö) formed a minority government with the support of the FPÖ and - to the dismay of many and in spite of strong opposition from within his own party - appointed four former NSDAP members to ministerial posts. This confirmed the FPÖ's participation in mainstream Austrian politics, signalling "that the sPÖ, to gain power, could do business with former Nazis in a pragmatic way".38 In 1986, the FPö's national convention witnessed a coup led by

Schiedel, Neugebauer (2002), p. 16; see Rheindorf, Wodak (2019) for an extensive overview of the FPÖ's history.

Manoschek (2002), p. 7 .

35 Schiedel, Neugebauer (2002), p. 16.

$36 \quad$ Manoschek (2002), p. 6.

37 Manoschek (2002), p. 7 .

38 Wodak et al. (1990), p. 290. 
Jörg Haider, who became the new chairman of the party. Haider's rise marked the turn of the majority of the FPÖ to radical and nationalist/nativist views. Employing strongly antisemitic, anti-foreigner and revisionist slogans, Haider led the FPö to successful elections at all levels. In the national election of 1999, the FPÖ received $26.91 \%$ and, for the first time in its history, took second place. After relatively brief negotiations, the FPÖ signed a coalition agreement with the övp (which had achieved third place) and entered the federal government in early 2000. This was the first time a far-right populist party came to power in an EU member state.

Although sanctions against the Austrian government were eventually introduced by the 14 other EU member states, it was not this external pressure but the controversial performance of the ÖVP-FPÖ government which pushed the FPö into gradual decline. At the next parliamentary elections on 1 October 2006, the FPÖ (headed by Heinz-Christian Strache, a former confidante of Haider) and the Bündnis Zukunft Österreich (BzÖ, a splinter group headed by Haider) managed a combined $15.1 \%$. Thus, after six years in government, the FPÖ returned to its oppositional role until the FPÖ again formed a coalition government with the ÖVP on 19 December 2017 after the national election on 11 October 2017, where they achieved third place with $26 \%$ of the votes.

\subsection{The Backstage: Programmatic Utterances and Party Programs ${ }^{39}$}

No public figure represents extreme-right ideology within the FPÖ better than Johann Gudenus, former head of the FPÖ's Vienna chapter and the FPÖ's former party whip in parliament (2018-2019). Gudenus studied law in Vienna and Russian in Moscow, and completed an MA at the Diplomatic Academy of Vienna. He opposed the EU's sanctions against Russia, and held a sceptical stance towards the EU. Gudenus (whose father was convicted of Holocaust denial) is well-known for his explicit racist, nativist, antisemitic and homophobic utterances on the backstage of the party's activities which have frequently been leaked to the press and caused multiple scandals. ${ }^{40}$

Addressing closed publics, Gudenus has often voiced extreme right positions in surprisingly explicit terms. This has included, for example, racial policies for the so-called 'purity of Europe': "Europe is the cradle of the white race. We demand a Europe-wide, coordinated policy for the family and reproduction,

39 See Rheindorf, Wodak (2019) for more details of the FPö's gender, identity and body politics and its success in penetrating popular culture.

40 See Pollak (2015); Wodak (2019a). After the so-called 'Ibiza-Scandal', Gudenus was excluded from the FPÖ (see Wodak 2020 for details). 
including a commitment to the fact that Europe is white." ${ }^{31}$ It also included defamation of political opponents with antisemitic slurs: "If you mix red and green together, you get yellow. And yellow is the colour of Judas, it is the colour of treachery." ${ }^{2}$ And it included a clear denial of basic human rights ("Asylum is not a human right"), ${ }^{43}$ as well as homophobic, conspiracy theory-based projections of a doomed nation: "The powerful European lobby of homosexuals wants absolute equality for homosexuals and lesbians. It is hard to imagine where all this will lead." 44 Due to his former high-ranking position and frequent appearances in television debates and interviews, Gudenus' more public performances directly recontextualised backstage agenda into frontstage policies.

Gudenus' utterances bear a strong similarity to the party-affiliated publication Für ein freies Österreich [For a Free Austria], written by Michael Howanietz, a local FPÖ politician. ${ }^{45}$ Albeit not officially party doctrine, the book also closely mirrors the Handbuch freiheitlicher Politik [Handbook of FPÖ Politics], drafted by the party leadership to serve as an internal guideline for party functionaries regarding key policy areas. The focus here is - just very briefly - on the former publication as it constitutes a less constrained articulation of far-right and extreme-right ideologies, free of the rhetorical limitations that even the FPÖ, as an established party, should follow according to post-war conventions.

As Für ein freies Österreich is accompanied by endorsing forewords written by then FPÖ's chairman, Hans-Christian Strache, and current chairman, Norbert Hofer who stood as candidate for Austrian President in 2016 and was minister for infrastructure and transport in the coalition government (2018-2019), it is obvious that the party leadership agreed with the ideologies propagated in

41 Tangente 3/2004, magazine of the FPö's youth organisation "Ring Freiheitlicher Jugend" under chairman Johann Gudenus. This and all subsequent translations by Markus Rheindorf and Ruth Wodak. See Rheindorf, Wodak (2019) for more examples, a comprehensive overview and in-depth analysis.

Johann Gudenus at a rally in 2011, reported by the FPö's newspaper Neue Freie Zeitung, 27.10.2011, p. 8. See report and analysis, available on-line at https://www.stopptdierechten. at/2011/10/31/gudenus-und-die-farbe-des-judas/ [accessed 26.04.2019].

Johann Gudenus, press release on 19.12.2014, available online at www.ots.at/presseaussendung/OTS_20141219_OTSoo76 [accessed 01.07.2017].

44 Johann Gudenus in a speech given in Moscow on 11 September 2014. See report in the weekly Profil, 13 September 2014, available on-line at https:/www.profil.at/oesterreich/ fpoe-moskau-gudenus-eu-usa-nato-homosexuellenlobby-377959 [accessed 26.04.2019], and the interview with Johann Gudenus after his return from Moscow in the broadsheet Kurier, 19 September 2014 [accessed 26.04.2019].

See Rheindorf, Wodak (2019). 
this text. However, on frontstage (see below), these ideologies and statements are backgrounded. Indeed, after the Austrian national election on 15 October 2017 and the establishment of a coalition government between Sebastian Kurz' Neue öVP and the FPö, Hans-Christian Strache attempted to perform a soft version of the FPÖ's programmatic elements, via indirect and coded language as well as by denial of past explicit discriminatory utterances and propositions. However, this attempt frequently failed as the many breaches of taboos (in respect to Nazism, antisemitism, homophobia, and so forth) illustrate. ${ }^{46}$

In sum, the programmatic text (which has been extensively analysed elsewhere $)^{47}$ defines itself as a call for "an autonomous, independent country ", i.e. independent of transnational organisations, international law, international economy, the exchange of goods, which are all listed as ways in which Austria is being controlled by others. ${ }^{48}$ Significantly, the various argumentative strands of the book - all ultimately intended to save Austria from an alleged immanent doom - are linked to the extreme-right's ideologies and discursive constructions of the national body and related nativist body politics. ${ }^{49}$ In this way, the book calls for "an independent country that depends on its many existent strengths, its nature, its infrastructure and the productive power of its people".50

In the apocalyptic worldview propagated throughout the book, migrants are perceived as a threat precisely because they allegedly possess stronger identities: Their "assault" or slow invasion to "demographically displace" the Austrian people makes the latter "a species on the brink of extinction".51 The gravest threat to the nation, however, is identified in an imagined decaying national pride: Honour and loyalty to the community of the nation are the foundation for loyalty and faithfulness in the heterosexual relationship. ${ }^{52}$

In this way, the ultimate Feindbild emerges: women and men who have adopted new life styles and gender roles - integrating new family patterns, mobility, diversity, career, and shared child care. White male patriarchy is perceived as being under threat, simultaneously endangered by the alleged invasion of the so-called 'cultural other'.

\footnotetext{
$46 \quad$ See Wodak (2018); Wodak (2019b).

47 See Rheindorf, Wodak (2019).

48 See Howanietz (2013), p. 6.

49 See e. g. Musolff (2010); Wodak (2015a).

50 Howanietz (2013), p. 7 .

$5^{1} \quad$ Howanietz (2013), p. $19 f$.

$5^{2}$ Howanietz (2013), p. 31. "Ehre" and "Treue", the two concepts the book praises in this context, formed the core of the ss motto "Meine Ehre heißt Treue", which is banned under the Austrian Verbotsgesetz. See Engel, Wodak (2013).
} 
Comparing this inner weakness to the external threat identified as migrants, the book finally offers two alternative options for the future: The "true" Austrian "Volk" will, the FPÖ argues, employing the typical and traditional racist discourse about parasites, either slowly degenerate and die off, "eaten from the inside like wasp larvae eat maggots"; 53 or current developments will lead to a violent "civil war",54 thus triggering fear and anxiety. The danger scenarios are manifold; uncertainty, fear, and anger are produced and reproduced, and fallacious arguments are provided as legitimation. The author clearly prefers the latter, arguing that like any conflict it would be "productive" and "awaken potential". ${ }^{55}$ Either way, he concludes, "Europe will burn."56

\subsection{Frontstage: The Extreme Right in Election Campaigns}

Since Heinz-Christian Strache took control of the F PÖ in 2005, frontstage activities of the party - particularly in election campaigns and social media - have seen an obvious and clear increase of banal nationalism: displaying the Austrian flag, singing the national anthem, and showing an abundance of other symbols of national pride.

As argued by Forchtner et al., the manifold patterns of media communication and the clever and ubiquitous appropriation of media agenda and frames employed in the recent success of populist-right and extreme-right parties cannot be dismissed or marginalised as a mere coincidence. ${ }^{57}$ As Bos, van der Brug \& de Vreese illustrate, successful far-right populist leaders have actually managed to achieve a delicate balance between, on the one hand, appearing innovative and anti-establishment, and, on the other, authoritative and legitimate; thus they counter the élites but do not oppose the liberal democratic system per se. ${ }^{58}$ Frequently, this is achieved by scandalisation and the intentionally and continuously provoked dynamic of the so-called far-right populist perpetuum mobile, ${ }^{59}$ or by what labels as "dramatisation", i.e., "the need to generate tension in order to build up support for the party [...] by denouncing the tragedies that would befall the community if it were to be deprived of its defenses". 60

\footnotetext{
$53 \quad$ Howanietz (2013), p. 117.

54 Howanietz (2013), p. 121.

55 Howanietz (2013), p. 113.

56 Howanietz (2013), p. 134.

57 See Forchtner et al. (2013).

$5^{8}$ See Bos, van der Brug, de Vreese (2011).

59 See Wodak (2013a); Wodak (2013b); Wodak (2015a), p. 19f; Wodak (2020), p. 25f.

6o Albertazzi (2007), p. 335.
} 
Scandalisation also implies manifold references to the allegedly charismatic leaders of such parties, who construct themselves as saviours, problem solvers and crisis managers, which may lead voters to have more confidence in the effectiveness of the politics of the populist far-right. The way the tension between extraordinariness and being 'one of us', i.e., being 'authentic', was cleverly managed by former F PÖ leader Jörg Haider on front stage and further developed by his successor, HC Strache (as he was branded) in many different publics and genres, ${ }^{61}$ from TV interviews to snippets caught on video while dancing in a disco, from pamphlets and manifestos to posters and comic booklets, all of which are accessible on Hc Strache's homepage ${ }^{62}$ and disseminated via Facebook. 63

Indeed, the FPÖ maintains its Web presence via the main party web page (www.fpoe.at) and a party-related think-tank (www.fpoe-bildungsinstitut.at). Members of the FPÖ also operate a blog called "Uncensored" (www.unzensuriert. at) ${ }^{64}$ and an official YouTube channel (www.youtube.com/ Oesterreichzuerst) called "Austria First", a name employed in many campaigns and major referenda undertaken by the party in both the 1990s and 20oos. The YouTube Channel utilizes a variety of genres, ranging from recordings of HC Strache's speeches and interviews to his rap-songs (see below) and different election-campaign spots and short films. Before his exclusion from the F PÖ in November 2019, the party also managed the Web presence of its leader - via his Web page (www. hc-strache.at) as well as channels on Facebook (www.facebook.com/HCStraa che?ref=mf) and Flickr (www.flickr.com/search/?q=strache\&w=all) - after Strad che's exclusion from the FPÖ, his homepage was closed down.

Following Alexander, the symbolic dimension of 'doing politics' must be understood as central to all efforts of a politician's performance, in the media, at election rallies, in parliament, at press conferences, and so forth. ${ }^{65}$ Alexander

$61 \quad$ See Forchtner et al. (2013); Wodak (2011) as well as Wodak, Forchtner (2018) for more details on the fictionalisation of politics.

62 See http://www.hcstrache.at/home/ [accessed 02.05.2017].

63 See Köhler, Wodak (2012); Wodak, Köhler (2010); Wodak (2013a); Wodak (2013b); Wodak (2020) for recent detailed studies and research on the FPö's and HC Strache's media policies as well as on his downfall and exclusion from the FPÖ in November 2019.

64 The blog - there is now also a print edition - was initiated by Martin Graf, a member of a far-right fraternity and former third president of the Austrian parliament. According to the Austrian chamber of commerce. See http://www.wkoecg.at/Web/Ecg.aspx?FirS maID=of68efff-25b9-46cd-gedd-b18a79agb92d [accessed 22.10.2012], it is now managed by Walter Asperl, who was also Graf's office manager during his time in parliament as third president of the chamber.

65 See Alexander (2006); Forchtner et al. (2013); Wodak (2020), pp. 188-92. 
also argues that these performances must hook into the background culture, symbols, narratives and myths of the respective society to be successful. In other words: If such symbolic practices are supposed to resonate, they should draw on, and mobilize, a common cultural structure, via appeals to common knowledge of epistemic communities, to the endoxa by using presuppositions, insinuations and other pragmatic devices as well as specific argumentation schemes. As Tannen succinctly notes in her best-selling book The Argument Culture, "fitting ideas into a particular camp requires you to oversimplify them. Again, disinformation and distortion can result. Less knowledge is gained, not more. And time spent attacking an opponent or defending against attacks is not spent doing something else".66 It is thus certainly legitimate to ask at this point what kind of specific performativity characterizes far-right populist politicians differently than politicians per se.

The form of the performance is only one - even if important - part of the specific far-right populist habitus. Form and content are necessarily linked to construct the specific political agenda. In such populist rhetoric, several elements are thus combined: specific topics which are addressed; specific ideologies which feed into and constitute utterances and performances; strategies of calculated ambivalence and provocation which are used to create and deescalate intentionally provoked scandals; and a continuous campaigning style, an overall antagonistic habitus which does not comply with hitherto conventional rules of negotiation and compromise. ${ }^{67}$

The many positionings of HC Strache constructed a multi-faceted politicians' identity, oriented towards some and excluding others: as saviour of the Occident; as casual, smiling but also serious statesman; as fighter; as attractive young man; as extreme right-wing fraternity member with paramilitary experience; and as hero, revolutionary and superman, surrounded by loyal supporters, cheerleaders, body guards, and smiling young men and women. ${ }^{68}$ In this way, one could reiterate that Strache - like his predecessor Haider before him - had been a "man of all seasons", ${ }^{69}$ adaptable to the needs and desires of ordinary people, bonding with them as well as representing them. The party, through all of this, had been metonymically identified with him and his agenda, consisting mainly of anti-immigration policies, anti-EU agenda and nativist nationalism as well as explicit insinuations of Nazi ideology and a revisionist conception of Austria's (and Germany's) history.

\footnotetext{
66 Tannen (1998), p. 289.

$67 \quad$ See Forchtner et al. (2013).

68 Analyzed in more detail in Wodak (2015a), pp. 136-141.

69 See Gingrich (2002).
} 


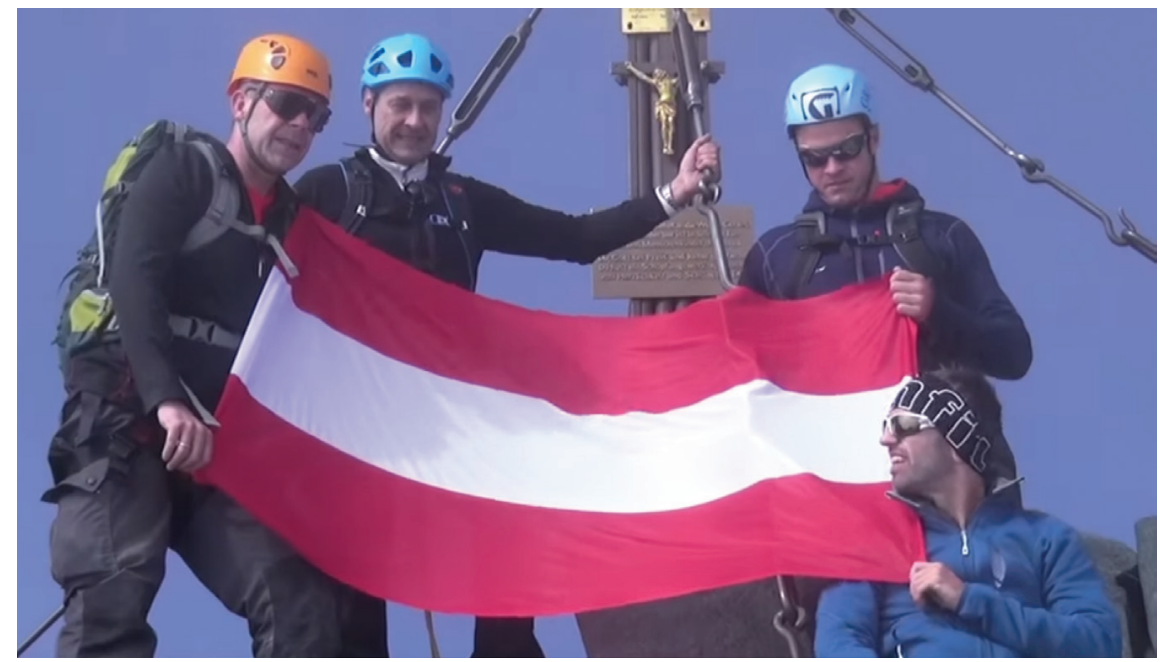

FIGURE 5.2 Vilimsky (MEP), Strache, Gudenus and Kickl (Party Secretary) brandishing the Austrian flag at the Großglockner peak (Austria's highest mountain)

In terms of national identity, the symbols which had been used by the Strache-FPÖ are linked to deeply conservative constructions of the national body, e.g. rural landscapes, snow-covered mountain tops, traditional agriculture and farmers, religious symbols of Christianity. In many images and aspects, the respective texts and performances feature Strache himself enacting and employing these symbols (see Figure 5.1).

Since these are symbols of the nation rather than the party, their recontextualisation and resemiotisation by the FPÖ continue to constitute a provocative appropriation linked to the FPÖ's claim to be the only party to represent 'the people' and the nation or 'Heimat'. Indeed, ever since Strache's leadership one is confronted with a re-branding of the FPÖ as the "Soziale Heimatpartei", the Social Homeland Party (a label it shares with the extreme-right NPD of Germany).

Two such provocations relate to Austria's national anthem: firstly, publicly refusing to sing the amended national anthem (since 2011, the lyrics include "daughters" alongside "sons"), thus breaking the respective relevant law, and secondly, using an alternative anthem for their campaigns, titled "Immer wieder Österreich". The lyrics of this song incorporate the well-known chorus of soccer fans at games of Austria's national team - "Immer wieder, immer wieder, immer wieder Österreich" "Time and again, time and again, time and again Austria") - but also appeal to the "honesty, righteousness and loyalty" of all true Austrians and call on them to "pledge" their loyalty to "their country". The accompanying video resemiotises the lyrics of the actual Austrian anthem and alludes to the aesthetics of Nazi era films such as Leni Riefenstahl's work (see 


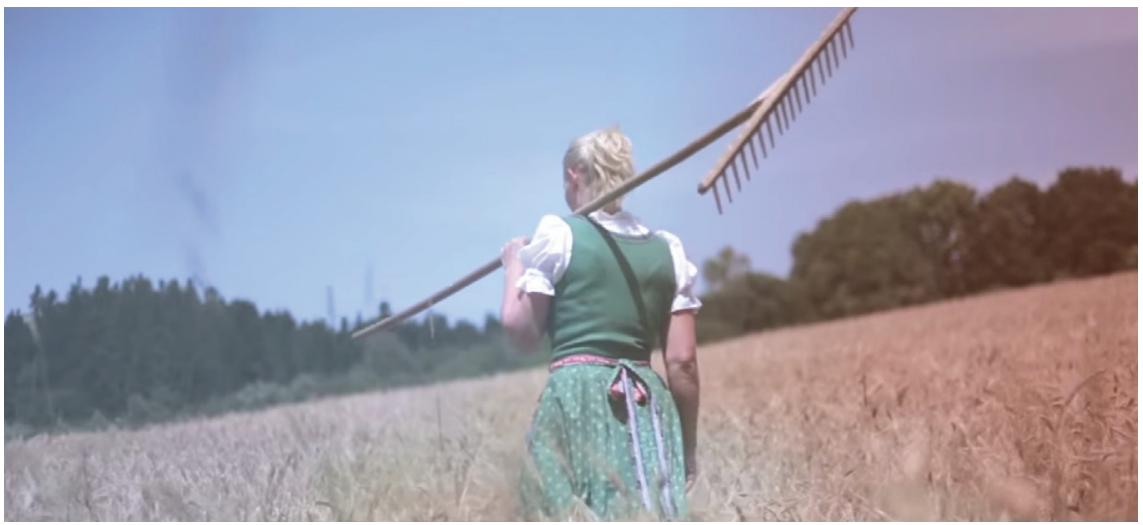

FIGURE 5.3 Still from the FPÖ's alternative anthem and election campaign video

Figure 5.2). Such discursive strategies of anthropomorphising, culturalising and ethnicising the national body go back many years. Indeed, the frontstage politics of the far-right in Austria are eminently culturalist and biologist. ${ }^{70}$

The dynamics of everyday performances frequently transcend careful analytic categorisations; boundaries between categories are blurred and flexible, open to change and to ever new socio-economic developments. In sum, when analysing far-right (or, indeed, left-wing) populist movements and their rhetoric, it is essential to recognize that their propaganda - realised as it is in many genres across relevant social domains - always combines and integrates form and content, targets specific audiences and adapts to specific contexts. Only by doing so, are we able to deconstruct, understand and explain their messages, the resonance of their slogans and their electoral success.

In the body and social politics of such ideologies, the 'national family' must preserve the traditional paternalistic order of the sexes and maintain the nation's body as white and pure. This draws on conservative and fascist imaginaries as extensively investigated by Musolff and Richardson in their research on the concept of the 'Volk' and the 'Volkskörper' across German and British nationalistic writing since the eighteenth century. ${ }^{71}$ In summary, the extreme-right's salient construction of the national body and use of associated

70 See Krzyżanowski, Wodak (2009); Wodak, Köhler (2010); Rheindorf, Wodak (2019).

71 See Musolff (2010); Richardson (2017). 
symbols shows a constant effort to mobilize feelings of national pride but equally of national emergency, of threat and danger, of the possible decay of the Western World.

Finally, it must be emphasised that the FPÖ as the only established party in Austria which has consistently provided a home for extreme-right positions is far from homogenous. The ideological positions articulated by its leading figures range from extreme-right and pan-German nationalism to toned-down positions, particularly on the frontstage. Indeed, the ability to alternate between 'strong' and 'soft' performances according to context and audience is a defining characteristic of the contemporary far right in Austria. Both allusions to and encoded references to extreme-right and Nazi ideologies are thus part of the strategy of calculated ambivalence that ensures deniability. Closely related to these strategic performances are processes of normalisation, transcending and breaking taboos through recontextualisation and resemiotisation as aspects of extreme-right imaginaries, moving from backstage to frontstage and from party politics to the mainstream.

Such normalisation processes became highly evident in the Austrian national election 2017 where the Austrian People's Party under its new leader Sebastian Kurz appropriated far-right agendas in respect to migration and asylum issues, thus normalising important elements of the FPÖ's far-right program. This strategic, cleverly designed and marketised election campaign illustrates well how normalising procedures were employed in many genres and across social and political fields, on national, regional, and local levels. ${ }^{72}$ In addition, the governing ÖVP (in its coalitions with both the FPÖ until 2019 and with the Green Party since 2020) has implemented its own version of 'message control'73 which supports top-down normalisation: Each week, a specific topic is launched in a press conference and elaborated on for one week, until being replaced with a new agenda seven days later. For example, while discontent and strikes were contemplated against a new law allowing for 12-hour working days and 6o-hour working weeks if employees voluntarily comply with their employer's request (implemented with 1 September 2018), the government launched various news items about a ban of headscarves for Muslim girls in kindergarten and pre-school. In this way, the government pleased their electorate with anti-Muslim and anti-immigration agendas, while being aware that the core electorate of the FPÖ would be enraged by such new labour laws, which were upsetting the post-war consensus of the social welfare state.

72 See Wodak et al. (2020) for details.

73 John, Mittelstaedt (2018). 
The media have thus been kept busy debating 'the headscarf', while being distracted from other relevant news stories.

As noted by Uitz ${ }^{74}$ of Orbán's Hungary, parliamentary procedures are also frequently neglected since 2018. Discussion and consultations with experts, the opposition, and journalists seem to be out of the question in Kurz's Austria ${ }^{75}$. In sum, it seems that the new Austrian People's Party (ÖVP) - in its streamlined trajectory to power (at least in the sense of leading coalition governments since 2018) - has either ignored or quietly accepted some non-democratic practices, thus normalising the previously unsayable and unacceptable.

\section{Bibliography}

Adorno, Theodor (1966). Negative Dialektik (Frankfurt a.M.: Suhrkamp).

Albertazzi, Daniele (2007). 'Addressing "the People". A Comparative Study of the Lega Nord's and Lega dei Ticinesi's Political Rhetoric and Style of Propaganda', Modern Italy, 12.3, pp. 327-347.

Alexander, Jeffrey C. (2006). The Civil Sphere (Oxford: Oxford University Press).

Anderson, Benedict ([1985] 1995). Imagined Communities. Reflections on the Origin and Spread of Nationalism (London: Verso).

Berger, Ernst, Ruth Wodak (eds) (2018). Kinder der Rückkehr. Geschichte einer marginalisierten Jugend (Berlin: Springer).

Billig, Michael (1995). Banal Nationalism (London: Sage).

Blackledge, Adrian (2009). Discourse and power in a multilingual world (Amsterdam: Benjamins).

Bos, Linda, Wouter van der Brug, Claes H. de Vreese (2011). 'How the Media Shape Perceptions of Right-Wing Populist Leaders', Political Communication, 28.2, pp. 182-206.

Boukala, Salomi (2013). The Greek Media Discourse and the construction of European Identity. Islam as Radical Otherness, collective identity and 'Fortress Europe' (Ph.D. Thesis: Lancaster University).

Bourdieu, Pierre (1990). The Logic of Practice (Cambridge: Polity Press).

Bourdieu, Pierre (1994). 'Rethinking the State. Genesis and Structure of the Bureaucratic Field', Sociological Theory, 12.1, pp. 1-18.

Breuss, Susanne, Karin Liebhart, Andreas Pribersky (1995). Inszenierungen. Stichwörter zu Österreich. (Wien: Sonderzahl).

$74 \quad$ Uitz (2015).

75 See Wodak (2019a); Wodak (2019b) for details and a comprehensive analysis of developments in Austria since 2018. 
De Cleen, Benjamin (2012). The rhetoric of the Flemish populist radical right party Vlaams Blok/Belang in a context of discursive struggle. A discourse-theoretical analysis (Ph.D. Thesis: Vrije Universiteit Brussels).

Delanty, Gerard, Krishan Kumar (2006). 'Introduction', in Gerard Delanty, Krishan Kumar (eds), The Sage Handbook of Nations and Nationalism (London: Sage), pp 1-4.

Engel, Jakob, Ruth Wodak (2013). "Calculated Ambivalence” and Holocaust Denial in Austria', in Ruth Wodak, John E. Richardson (eds) Analysing Fascist Discourse. European Fascism in Talk and Text (London: Routledge), pp. 73-96.

Forchtner, Bernhard, Michal Krzyżanowski, Ruth Wodak (2013). 'Mediatisation, RightWing Populism and Political Campaigning. The Case of the Austrian Freedom Party (FPÖ)', in Mats Ekström, Andrew Tolson (eds), Media Talk and Political Elections in Europe and America (Basingstoke: Palgrave), pp. 205-228.

Frindte, Wolfgang, Nico Dietrich (eds) (2017). Muslime, Flüchtlinge und Pegida. Sozialpsychologische und Kommunikationswissenschaftliche Studien in Zeiten globaler Bedrohungen (Wiesbaden: Springer).

Gellner, Ernest (1983). Nations and Nationalism (Oxford: Blackwell).

Gingrich, Andre (2002). 'A Man for all Seasons. An Anthropological Perspective on Public Representations and Cultural Politics of the Austrian Freedom Party', in Ruth Wodak, Anton Pelinka (eds), The Haider Phenomenon in Austria (New Brunswick: Transaction Press), pp. 87-102.

Griffin, Roger (1999). 'Afterword. Last Rights?', in Sabrina P. Ramet (ed.), The Radical Right in Central and Eastern Europe since 1989 (Pennsylvania: Penn State Univ. Press), pp. 297-321.

Halbwachs, Maurice (1967). Das kollektive Gedächtnis (Stuttgart: Enke).

Hall, Stuart (ed.) (1996). Questions of cultural identity (London: Sage).

Haller, Max et. al. (eds) (1996). Identität und Nationalstolz der Österreicher. Gesellschaftliche Ursachen und Funktionen - Herausbildung und Transformation seit 1945 - Internationaler Vergleich. (Wien: Böhlau).

Howanietz, Michael (2013). Für ein freies Österreich. Souveränität als Zukunftsmodell (Wien: Freiheitlicher Parlamentsklub).

John, Gerhard, Katharina Mittelstaedt (2018). ,Wie Türkis-Blau Widersprüche wegredet', Der Standard, 28 February, available on-line at https://derstandard.at/ 2000075143822/Wie-Tuerkis-Blau-Widersprueche-wegredet [accessed 26.04.2019].

Köhler, Katharina, Ruth Wodak (2012). 'Mitbürger, Fremde und "echte Wiener" - Einund Ausgrenzungen über Sprache. Diskursive Konstruktion von Macht und Ungleichheit am Beispiel des Wiener Wahlkampfes 2010', Deutschunterricht, 6.11, pp. $64-74$.

Krzyżanowski, Michal (2010). The discursive construction of European identities. A multi-level approach to discourse and identity in the transforming European Union (Frankfurt a.M.: Lang). 
Krzyżanowski, Michal, Ruth Wodak (2009). The Politics of Exclusion. Debating Migration in Austria. (New Jersey: Transaction Publishers).

Manoschek, Walter (2002). 'FPÖ, ÖVP and Austria's Nazi Past', in Ruth Wodak, Anton Pelinka (eds), The Haider Phenomenon in Austria (New Orleans: Transaction Press), pp. $3^{-16 .}$

Mudde, Cas (2007). The Populist Radical Right Parties in Europe (Cambridge: Cambridge University Press).

Musolff, Andreas (2010). Metaphor, Nation, and the Holocaust (London: Routledge).

Pollak, Alexander (2015). Der Hassprediger. Der aufhaltsame Aufstieg des Johann G. Ein Beipacktext zur Wiener Wahl (Wien: Czernin).

Rathkolb, Oliver (2011). Die paradoxe Republik (Innsbruck, Wien: Haymon-Verlag).

Reisigl, Martin, Ruth Wodak (2009). 'The Discourse-historical Approach (DHA)', in Ruth Wodak, Michael Meyer (eds) (20o9). Methods of Critical Discourse Analysis (London: Sage), pp. 87-121.

Reisigl, Martin, Ruth Wodak (2001). Discourse and Discrimination. Rhetorics of Racism and Antisemitism (London: Routledge).

Rheindorf, Markus, Ruth Wodak (2018). 'Borders, Fences and Limits. Protecting Austria from Refugees. Metadiscursive negotiation of meaning in the current refugee crisis', Journal of Immigrant \& Refugee Studies. https://www.tandfonline.com/doi/full/10.1 o8०/15562948.2017.1302032 [accessed 12.01.2019].

Rheindorf, Markus, Ruth Wodak (2019). “Austria First” Revisited. A diachronic cross-sectional analysis of the gender and body politics of the extreme right', Patterns of Prejudice, 53.3, special issue, ed. by Bernhard Forchtner, Christopher Kolvraa, pp. 302-320.

Ricento, Thomas (2003). 'The Discursive Construction of Americanism', Discourse \& Society, 14.5 , pp. $611-637$.

Richardson, John E. (2017). 'Fascist Discourse', in John Flowerdew, John E. Richardson (eds), The Routledge Handbook of Critical Discourse Studies (London: Routledge), pp. 447-462.

Schiedel, Heribert, Wolfgang Neugebauer (2002). 'Jörg Haider, die FPÖ und der Antisemitismus', in Anton Pelinka, Ruth Wodak (eds), "Dreck am Stecken". Politik der Ausgrenzung (Wien: Czernin), pp. 11-31.

Sicurella, Federico Giulio (2015). Speaking for the Nation. A critical discourse study of intellectuals and nationalism in the post-Yugoslav context (Ph.D. Thesis: Lancaster University).

Skenderovic, Damir (2009). The Radical Right in Switzerland. Continuity and Change 1945-2000 (New York: Berghahn Books).

Tannen, Deborah (1998). The Argument Culture. Moving from Debate to Dialogue (New York: Random House).

Uitz, Renate (2015). 'Can you tell when an illiberal democracy is in the making? An appeal to comparative constitutional scholarship from Hungary', I.Con, 13.1, pp. 279-30o. 
Van Dijk, Teun A. (1991). News as Discourse (New York: Erlbaum).

Walton, Douglas ([1970] 1996). Argumentation Schemes for Presumptive Reasoning (New Jersey: Erlbaum).

Wodak, Ruth ([2009] 2011). The Discourse of Politics in Action. Politics as Usual (Basingstoke: Palgrave).

Wodak, Ruth (2013a). “Anything goes!” The Haiderization of Europe', in Ruth Wodak, Majid KhosraviNik, Brigitte Mral (eds), Right-Wing Populism in Europe. Populism and Discourse (London: Bloomsbury), pp. 23-38.

Wodak, Ruth (2013b). 'The strategy of discursive provocation - a discourse-historical analysis of the FPÖ's discriminatory rhetoric', in Matthew Feldman, Paul Jackson (eds), Doublespeak. The Rhetoric of the Far-Rights since 1945 (Frankfurt a.M.: ibidem), pp. 101-122.

Wodak, Ruth (2014). 'Political discourse analysis. Distinguishing frontstage and backstage contexts. A discourse-historical approach', in J. Flowerdew (ed.), Discourse in Context (London: Bloomsbury), pp. 321-45.

Wodak, Ruth (2015a). The Politics of Fear. What Right-wing Populist Discourses Mean (London: Sage).

Wodak, Ruth (2015b). "Normalisierung nach rechts". Politischer Diskurs im Spannungsfeld von Neoliberalismus, Populismus und kritischer Offentlichkeit', Linguistik Online, 73, 4-15.

Wodak, Ruth (2017). 'The Establishment, the Elites, and the People. Who's who?', Journal of Language and Politics, special issue, ed. by Ruth Wodak, Michal Krzyżanowski, pp. 1-15. DOI: 10.1075/jlp.1703o.wod.

Wodak, Ruth (2019a). 'The micro-politics of right-wing populism', in Gregor Fitzi, Jürgen Mackert, Bryan S. Turner (eds), Populism and the Crisis of Democracy (London: Routledge), pp. 11-29.

Wodak, Ruth (2019b). 'Entering the "Post-Shame era", The rise of illiberal democracy, populism and neo-authoritarianism in Europe. The case of the turquoise-blue government in Austria 2017/2018', Global Discourse, special issue, ed. by Russel Foster, Jan Grzymski, The Limits of Europe, doi.org/10.1332/204378919X15470487645420.

Wodak, Ruth (2020). The Politics of Fear. The shameless normalisation of far-right discourse. (London: Sage; 2nd revised and extended edition).

Wodak, Ruth, Bernhard Forchtner (2018). 'The Fictionalisation of Politics', in Ruth Wodak, Bernhard Forchtner (eds), Routledge Handbook of Language and Politics (London: Routledge), pp. 572-586.

Wodak, Ruth, Katharina Köhler (2010). 'Wer oder was ist "fremd"? Diskurshistorische Analyse fremdenfeindlicher Rhetorik in Österreich', Sozialwissenschaftliche Studien 1, pp. 33-55. 
Wodak, Ruth, Rudolf de Cillia, Markus Rheindorf, Sabine Lehner (2020). Österreichische Identitäten im Wandel. Empirische Untersuchungen zu ihrer diskursiven Konstruktion 1995-2015. (Berlin: Springer).

Wodak, Ruth, John E. Richardson (eds) (2013). Analysing Fascist Discourse. European Fascism in Talk and Text (London: Routledge).

Wodak, Ruth, Rudolf de Cillia, Martin Reisigl, Karin Liebhart ([1999] 2009). The discursive construction of national identities (Edinburgh: Edinburgh University Press. 2nd revised edn).

Wodak, Ruth, Peter Nowak, Johan Pelikan, Helmut Gruber, Rudolf de Cillia, Richard Mitten (1990). "Wir sind alle unschuldige Täter!" Diskurshistorische Studien zum Nachkriegsantisemitismus (Frankfurt a.M.: Suhrkamp). 